\title{
POLICY DOCUMENTS
}

\section{EU}

Commission Delegated Regulation (EU). 2015/761 supplementing Directive 2004/109/EC of the European Parliament and of the Council with regard to certain regulatory technical standards on major holdings, 2015 O.J. L 120/2.

Directive 82/891/EEC based on Article 54 (3) (g) of the Treaty, concerning the division of public limited liability companies, 1982 O.J. L 378. ('Sixth Company Law Directive').

Directive 2004/109/EC of the European Parliament and of the Council on the harmonisation of transparency requirements in relation to information about issuers whose securities are admitted to trading on a regulated market and amending Directive 2001/34/EC, 2004 O.J. L 390/38. ('Transparency Directive').

Directive 2004/25/EC of the European Parliament and of the Council on take over bids, 2004 O.J. L 142/12. ('Takeover Directive').

Directive 2005/56/EC on cross-border mergers of limited liability companies, 2005, O.J. L 310/1. ('Directive on Cross-Border Mergers').

Directive 2006/43/EC of the European Parliament and of the Council on statutory audits of annual accounts and consolidated accounts, amending Council Directives 78/660/EEC and 83/349/ EEC and repealing Council Directive 84/253/EEC, 2006 O.J. L 157/87. ('Audit Directive').

Directive 2007/36/EC of the European Parliament and of the Council on the exercise of certain rights of shareholders in listed companies, 2007 O.J. L 157/87. ('Shareholder Rights Directive').

Directive 2011/35/EC of the European Parliament and of the Council concerning mergers of public limited liability companies, 2011 O.J. L 110/1. ('Third Company Law Directive').

Directive 2012/30/EU of the European Parliament and of the Council on coordination of safeguards which, for the protection of the interests of members and others, are required by Member States of companies within the meaning of the second paragraph of Article 54 of the Treaty on the Functioning of the European Union, in respect of the formation of public limited liability companies and the maintenance and alteration of their capital, with a view to making such safeguards equivalent, 2012 O.J. L 315/74. ('Capital Directive').

Directive 2013/50/EU of the European Parliament and of the Council amending Directive 2004/109/ EC of the European Parliament and of the Council on the harmonisation of transparency requirements in relation to information about issuers whose securities are admitted to trading on a regulated market, Directive 2003/71/EC of the European Parliament and of the Council on the prospectus to be published when securities are offered to the public or admitted to trading and Commission Directive 2007/14/EC laying down detailed rules for the implementation of certain provisions of Directive 2004/109/EC, 2013 O.J. L 294/13. ('Transparency Directive').

Directive 2014/56/EU of the European Parliament and of the Council amending Directive 2006/43/ EC on statutory audits of annual accounts and consolidated accounts, 2014 O.J. L 158/196. ('Audit Directive').

EC (1972). The fifth directive. COM (72) 887 final, 27 September 1972. Retrieved from http://aei. pitt.edu/8586/1/8586.pdf.

EC (2003). Communication from the commission to the Council and the European Parliament: Modernising company law and enhancing corporate governance in the European Union - A plan to move forward. COM (2003) 284 final, 21 May 2003. 
EC (2006a). Proposal for a Directive of the European Parliament and of the Council on the exercise of voting rights by shareholders of companies having their registered office in a Member State and whose shares are admitted to trading on a regulated market and amending Directive 2004/109/EC. COM (2005) 685 final, 5 January 2006.

EC (2006b). Impact Assessment. Annex to the Proposal for a Directive of the European Parliament and of the Council on the exercise of voting rights by shareholders of companies having their registered office in a Member State and whose shares are admitted to trading on a regulated market and amending Directive 2004/109/EC. SEC (2006) 181, 17 February 2006.

EC (2010). The review of the operation of Directive 2004/109/EC. SEC (2009) 611, 27 May 2010.

EC (2011a). Green Paper: The EU Corporate Governance Framework. COM (2011) 164 final, 5 April 2011.

EC (2011b). Proposal for a directive of the European Parliament and of the Council amending Directive 2006/43/EC on statutory audits of annual accounts and consolidated accounts. COM (2011) 778 final, 30 November 2011.

EC (2011c). Impact assessment: Commission staff working paper impact assessment accompanying the document proposal for a Directive of the European Parliament and of the Council amending Directive 2006/43/EC on statutory audits of annual accounts and consolidated accounts and a proposal for a regulation of the European Parliament and of the Council on specific requirements regarding statutory audit of public-interest entities. SEC (2011) 1384 final, 30 November 2011.

EC (2012a). Report from the Commission to the European Parliament, the Council, the European Economic and Social Committee and the Committee of the Regions application of Directive 2004/25/EC on takeover bids. COM (2012) 347 final, 28 June 2012.

EC (2012b). Proposal for a Directive of the European Parliament and of the Council on improving the gender balance among non-executive directors of companies listed on stock exchanges and related measures. COM (2012) 614 final, 14 November 2012.

EC (2014a). Proposal for a Directive of the European Parliament and of the Council amending Directive 2007/36/EC as regards the encouragement of long-term shareholder engagement and Directive 2013/34/EU as regards certain elements of the corporate governance statement. COM (2014) 213 final, 9 April 2014.

EC (2014b). Impact assessment accompanying the document proposal for a Directive of the European Parliament and of the Council on amending Directive 2007/36/EC as regards the encouragement of long-term shareholder engagement and Directive 2013/34/EU as regards certain elements of the corporate governance statement and Commission Recommendation on the quality of corporate governance reporting ('comply or explain'). SWD(2014) 127 final, 9 April 2014.

EP (2012). European Parliament resolution of 14 June 2012 on the future of European company law. 2012/2669 (RSP).

ESMA (2013). Information on shareholder cooperation and acting in concert under the Takeover Bids Directive, 12 November 2013, ESMA/2013/142, Public Statement.

SEC (2010). Securities and Exchange Commission. 17 CFR Parts 200, 232, 240 and 249, Facilitating shareholder director nominations. Retrieved from http://www.sec.gov/rules/final/2010/339136.pdf.

\section{FRANCE}

Sénat (2016). Projet de loi relatif à la transparence, à la lutte contre la corruption et à la modernisation de la vie économique: Rapport. Titre Vii - Dispositions De Modernisation De La Vie Économique Et Financière. Retrieved from http://www.senat.fr/rap/115-712-1/115-712-120. html\#toc248 


\section{THE NETHERLANDS}

Kamerstukken II (2002-2003), 28179, no. 41.

Kamerstukken I (2003-2004), 28179, B.

Kamerstukken II (2008-2009) 31746, no. 3 (Memorie van Toelichting).

Kamerstukken II (2009-2010), 31877, no. 3.

Kamerstukken II (2009-2010), 31877, no. 5. (Nota naar aanleiding van het verslag). 